Boise State University

ScholarWorks

Raptor Research Center Publications and

Presentations

Raptor Research Center

$12-1-2018$

Sex Determination by Morphological

Measurements of Young Rockhopper Penguins (Eudyptes chrysocome) During the Crèche Phase

Virginia Morandini

Oregon State University

Miguel Ferrer

Estación Biológica de Doñana (CSIC)

Lynelle Perry

Boise State University

Marc Bechard

Boise State University 


\title{
Sex Determination by Morphological Measurements of Young Rockhopper Penguins (Eudyptes chrysocome) During the Crèche Phase
}

\author{
Virginia Morandini ${ }^{1}$, Miguel Ferrer ${ }^{2, *}$, Lynelle Perry ${ }^{3}$ and Marc Bechard ${ }^{3}$ \\ ${ }^{1}$ Fish and Wildlife Research Unit, Department of Fisheries and Wildlife, Oregon State University, 104 Nash Hall, \\ Corvallis, Oregon, 97331, USA
}

${ }^{2}$ Applied Ecology Group, Estación Biológica de Doñana (CSIC), Avenida Americo Vespucio, 41092, Sevilla, Spain

${ }^{3}$ Raptor Research Center, Department of Biology, Boise State University, Boise, Idaho, 83725, USA

*Corresponding author; E-mail: mferrer@ebd.csic.es

\begin{abstract}
To provide an easy and reliable work tool to identify the sex of Rockhopper Penguin (Eudyptes chrysocome) chicks, we weighed and measured 95 nestlings in the crèche phase during 24-31 January 2017 on the Falkland Islands, Argentina. Sex was subsequently determined using DNA analyses of blood from the same individuals. Significant differences were found in bill length (exposed culmen), bill depth and width, flipper length, and diagonal tarsus, but stepwise discriminant analysis showed bill length to be the best predictor for sex determination. Our model correctly classified $82.7 \%$ of males and $90.2 \%$ of females (overall correct classification $86.2 \%$ ). Threshold bill length was $36.64 \mathrm{~mm}$, with values above this point being males and values below being females. Therefore, it appears that measuring bill length is an easy, immediate, and accurate method to sex Rockhopper Penguins during the crèche phase. Received 23 February 2018, accepted 19 April 2018.
\end{abstract}

Key words.-bill length, crèche phase, culmen, discriminant analysis, Eudyptes chrysocome, morphometric, nestlings, Rockhopper Penguins, seabirds, sex determination.

Waterbirds 41(4): 434-437, 2018

Easy and reliable methods to identify the sex of individuals are useful for the study of many aspects of avian biology. Active management, population dynamics and biological studies can require sexual determination in real time, with no opportunities to analyze DNA. Penguins generally exhibit sexual dimorphism as adults, with males larger and heavier than females, but generally differences are not evident enough to provide a reliable sexing method without DNA or morphometric confirmation (Poisbleau et al. 2010). The extent of this dimorphism may vary between species and subspecies (Warham 1972; Agnew and Kerry 1995; Arnould et al. 2004), and between age categories within the same species (Scolaro 1987; Setiawan et al. 2004). Due to this variation, it may be necessary to use an independent reference dataset per species, per subspecies and per age class to most accurately determine sex (Poisbleau et al. 2010).

Discriminant function analysis has often been used to sex species of birds that are sexually monochromatic but show sexual dimorphism in size (Brennan et al. 1991; Ferrer and de le Court 1992; Delgado and Penteriani 2004; Ferrer et al. 2016). Exter- nal morphometric measurements are taken from individuals of known sex to develop discriminant functions and then test them (Amat et al. 1993; Lorentsen and Røv 1994). William (1983) and Titus et al. (1984) have noted the power and limitation of these discriminant techniques.

In penguins, there are no reliable plumage differences that can be used to distinguish the sex of individuals visually (Davis and Spiers 1990; Marchant and Higgins 1990). Whereas penguins are dimorphic in body mass, this measure is usually unreliable due to its variability within and between years (Warham 1975; Davis and Spiers 1990). External morphometric indices have been used widely to assist in the sexing of penguins (Kerry et al. 1992; Amat et al. 1993; Agnew and Kerry 1995), and specifically of Rockhopper Penguins (Eudyptes chrysocome, Poisbleau et al. 2010). However, there are no published data on the morphometrics of young Rockhopper Penguins during the crèche phase. The purpose of this study was to gather data on morphometric indices to determine the most reliable means of sexing Rockhopper Penguin chicks in the field during the crèche period. 
Methods

Study Area

We conducted this study on Saunders Island $\left(51.37^{\circ} \mathrm{S}, 60.09^{\circ} \mathrm{W}\right)$, located in the northern part of the Falkland Islands. The Falkland Islands are home to King (Aptenodytes patagonicus), Gentoo (Pygoscelis papua), Rockhopper, and Magellanic (Spheniscus magellanicus) penguins, as well as Rock Shags (Phalacrocorax magellanicus), Imperial Cormorants (P. atriceps), and Black-browed Albatross (Thalassarche melanophrys). The Rockhopper Penguin is the smallest crested penguin with a weight of 2.0-3.5 kg. The Southern Rockhopper Penguin (E. c. chrysocome) has a global population of around 1 million birds, with one of the largest populations being in the Falkland Islands (Baylis et al. 2013).

Body Measurements and Molecular Sexing

We captured 95 nestling Rockhopper Penguins during 24-31 January 2017. All nestlings were randomly selected from colonies on Saunders Island. The sizes of the study colonies were $>300$ breeding pairs in all cases. All of the sampled birds were between 25-35 days of age, which is at the beginning of the crèche phase (Poisbleau et al. 2010). We measured all of the nestlings using calipers and a rule, and weighed them using a spring balance. We recorded body mass (to the nearest $10 \mathrm{~g}$ ). We measured bill length (exposed culmen; Amat et al. 1993), bill depth, bill width, flipper length (to the nearest $\mathrm{mm}$ ) and diagonal tarsus (to the nearest $0.1 \mathrm{~mm}$ ) with digital calipers (Ferrer et al. 2016). To reduce variability, most of the measurements $(>90 \%)$ were made by the same observer.

We analyzed DNA from blood samples that were extracted from the medial metatarsal (caudal tibia) vein and then placed into lithium heparin tubes. Sex was determined by means of PCR amplification of sections from the CHD1-Z and CHD1-W genes that are located on the avian sex chromosomes (Griffiths et al. 1998). Using this technique, we identified 41 females and 52 males from the 93 birds used in the discriminant analysis.

\section{Statistical Analyses}

Mean and standard deviation (SD) for all measurements were calculated for each sex. All six variables were normally distributed and met the conditions for homogeneity of variance. To check for overall differences in size between sex classes, we performed a MANOVA analysis. One-way analysis of variance (ANOVA) of all six morphometric measurements were conducted to look for differences in each one of the measurements. We then used forward stepwise discriminant analysis to build the best explanatory discriminant model with the minimum possible number of morphometric variables to accurately determine sex. Each variable was moved into the model in successive steps, with an $F=3.84$ to enter $(0.95$ probability) and $F=2.71$ to remove ( 0.90 probability). Wilks' lambda statistic was derived to quantify the discriminant power of each model. Finally, we used a Jackknife procedure as posterior cross-validations of the predictive accuracy of the resulting functions (Manly 1986). There are some alternative analyses like logistic regression and multimodel inference that could be used, but discriminant function analyses have been the most commonly used in analyzing sex differences in birds. For comparative proposes, we decide to use this approach. We conducted analyses using STATISTICA software (StatSoft, Inc. 2007).

\section{RESUlts}

Significant differences in overall size of the measurements were evident between the sexes (Table 1). Females were significantly smaller than males in all cases, with bill length and flipper length being the most dimorphic (Table 2). The stepwise discriminant analysis retained only bill length as the best predictor variable in the discriminant model and excluded all the other variables (Wilks' lambda $=0.573, F=$ 67.566, $P<0.001)$. The discriminant function was:

$$
\mathrm{D}=0.468 \text { (bill length) }-16.856
$$

Values of $\mathrm{D}>0$ identified males, and values of $\mathrm{D}<0$ identified females. This model correctly classified $82.7 \%$ of males and $90.2 \%$ of females (overall success was $86.2 \%$; 13 birds were misclassified). The Jackknife procedure also correctly classified $86.2 \%$ of the whole sample. By solving the function for $\mathrm{D}=0$, we obtained a threshold bill length of $36.64 \mathrm{~mm}$, with values above this point being males and values below it being females.

Table 1. Test of significance (with sigma-restricted parameterization) of the effect of sex in morphometric measurements of young Rockhopper Penguins using MANOVA.

\begin{tabular}{lcccccc}
\hline \hline Parameter & Test & Value & $F$ & Effect - df & Error - df & $P$ \\
\hline Intercept & Wilks' lambda & 0.0008 & $16,059.57$ & 6 & 86 & $<0.001$ \\
Sex & Wilks' lambda & 0.5488 & 11.78 & 6 & 86 & $<0.001$ \\
\hline
\end{tabular}


Table 2. Mean, SD and ANOVA analyses of morphometric measurements of Rockhopper Penguins during the crèche phase.

\begin{tabular}{|c|c|c|c|c|c|c|}
\hline \multirow[b]{2}{*}{ Parameter } & \multicolumn{2}{|c|}{ Males $(n=52)$} & \multicolumn{2}{|c|}{ Females $(n=41)$} & \multirow[b]{2}{*}{$F$} & \multirow[b]{2}{*}{$P$} \\
\hline & Mean & $\mathrm{SD}$ & Mean & SD & & \\
\hline Weight $(\mathrm{g})$ & $1,866.34$ & 344.24 & $1,686.58$ & 310.64 & 6.806 & 0.010 \\
\hline Bill length (mm) & 37.63 & 2.21 & 33.97 & 2.03 & 67.565 & $<0.001$ \\
\hline Bill depth (mm) & 19.09 & 1.93 & 18.20 & 1.28 & 6.390 & 0.013 \\
\hline Bill width (mm) & 15.29 & 1.35 & 14.70 & 1.20 & 4.763 & 0.031 \\
\hline Flipper length (mm) & 164.85 & 6.30 & 160.26 & 7.24 & 10.632 & 0.001 \\
\hline Diagonal tarsus (mm) & 28.14 & 2.39 & 26.89 & 1.99 & 7.133 & 0.008 \\
\hline
\end{tabular}

\section{Discussion}

The significant differences found in bill length between the sexes of Rockhopper Penguins on Saunders Island, Falkland Islands, are of little surprise. Comparisons of sexual dimorphism among penguins show that bill length is the most common and useful measurement to separate males from females (Kerry et al. 1992; Amat et al. 1993; Agnew and Kerry 1995; Poisbleau et al. 2010). The dimorphic nature of penguins has been well documented (Gales 1988; Davis and Spiers 1990; Murie et al. 1991; Agnew and Kerry 1995), and now it is possible to determine the sex of individual penguins of several species without invasive techniques.

Our results indicate significant size dimorphism between female and male Rockhopper Penguins during the crèche phase. Since there was considerable overlap in the ranges of some measurements, discriminant functions using morphometric measurements as predictor variables improved accuracy. The best model in our discriminant analysis showed a high level of overall correct classification of sex $(86.2 \%)$, supported by several statistics and cross-validations. On the other hand, although scarcely tested, even sexing birds using DNA amplification can provide wrong classifications due to sample contamination, experimental error and observer error, up to $20 \%$ of wrong classifications (Palma et al. 2001).

Measures like weight, wing length, flipper length or foot pad length are widely used in sex determination of birds (Amat et al. 1993; Hedd et al. 1998; Sagar et al. 1998; Copello et al. 2006), although these morphometric characters are quite variable and dependent on other factors. Weight has high variation, even within the same day, and is dependent on food eaten, stage of growth and environmental conditions. Flipper length and foot pad length are sensitive to the means of measurement, given a high variability both among observers and between repeat measurements by the same observer (Ferrer and de le Court 1992). For these reasons, morphometric variables derived from hard body structures like bills and bones (e.g., upper bill depth) are preferable as stable predictors (Counsilman et al. 1994).

In population dynamic studies, identification of sexes in dead birds (e.g., from skeletal material from depredated birds) is very important. Determination of sex on these carcasses would be of interest for population dynamic studies and can only be determined from measurements of bones or bills. Bill length would be useful in this sense, as often the skull remains intact.

\section{AcKNOWLEDGMents}

Fundacion Migres supported the present study. We thank Micky Reeves, N. Huin, the Falkland Government, and David and Suzan Pole-Evans for their support of this project. Procedures used in this study comply with the current laws for working on the Falkland Islands. Permits to work in the study area and on the Rockhopper Penguins were granted by the Falkland Government (R12/2014), as well as by the owners of Saunders Island. All applicable international, national, and/or institutional guidelines for the care and use of animals were followed.

\section{Literature Cited}

Agnew, D. J. and K. R. Kerry. 1995. Sexual dimorphism in penguins. Pages 299-318 in The Penguins: Ecol- 
ogy and Management (P. Dann, I. Norman and P. Reilly, Eds.). Surrey Beatty \& Sons, Chipping Norton, Australia.

Amat, J. A., J. Vinuela and M. Ferrer. 1993. Sexing Chinstrap Penguins (Pygoscelis antarctica) by morphological measurements. Colonial Waterbirds 16: 213-215.

Arnould, J. P. Y., P. Dann and J. M. Cullen. 2004. Determining the sex of little penguins (Eudyptula minor) in northern Bass Strait using morphometric measurements. Emu 104: 261-265.

Baylis, A. M. M., A. C. Wolfaardt, S. Crofts, P. A. Pistorius and N. Ratcliffe. 2013. Increasing trend in the number of southern Rockhopper penguins (Eudyptes $c$. chrysocome) breeding at the Falkland Islands. Polar Biology 36: 1007-1018.

Brennan, A. L., J. B. Buchanan, C. T. Schick and S. G. Herman. 1991. Estimating sex ratios with discriminant function analysis: the influence of probability cut points and sample size. Journal of Field Ornithology 62: 357-366.

Copello, S., F. Quintana and G. Somoza. 2006. Sex determination and sexual size-dimorphism in Southern Giant-Petrels (Macronectes giganteus) from Patagonia, Argentina. Emu 106: 141-146.

Counsilman, J. J., K. Nee, A. K. Jalil and W. L. Keng. 1994. Discriminant analysis of morphometric characters as a means of sexing mynas. Journal of Field Ornithology 65: 1-7.

Davis, L. S. and E. A. H. Spiers. 1990. Mate choice in penguins. Pages 377-397 in Penguin Biology (L. S. Davis and J. T. Darby, Eds.). San Diego Academic Press, San Diego, California.

Delgado, M. and V. Penteriani. 2004. Gender determination of Eurasian Eagle-Owls (Bubo bubo) by morphology. Journal of Raptor Research 38: 375-377.

Ferrer, M. and C. de le Court. 1992. Sex determination in the Spanish Imperial Eagle. Journal of Field Ornithology 62: 359-364.

Ferrer, M., V. Morandini, L. Perry and M. Bechard. 2016. Sex determination by morphological measurements of Black-browed Albatrosses (Thalassarche melanophrys) using discriminant analysis. Waterbirds, 39: 295299.

Gales, R. 1988. Sexing adult Blue Penguins by external measurements. Notornis 35: 71-75.

Griffiths, R., M. C. Double, K. Orr and R. J. G. Dawson. 1998. A DNA test to sex most birds. Molecular Ecology 7: 1071-1075.

Hedd, A., R. Gales and N. Brothers. 1998. Reliability of morphometric measures for determining the sex of adult and fledgling Shy Albatrosses, Diomedea cauta cauta, in Australia. Wildlife Research 25: 69-79.
Kerry, K. R., D. J. Agnew, J. R. Clarke and G. D. Else. 1992. Use of morphometric parameters for the determination of sex in Adélie penguins. Wildlife Research 19: 657-664.

Lorentsen, S.-H. and N. Røv. 1994. Sex determination of Antarctic Petrels Thalassoica antarctica by discriminant analysis of morphometric characters. Polar Biology 14: 143-145.

Manly, B. F. J. 1986. Multivariate statistical methods: a primer. Chapman and Hall, London, U.K.

Marchant, S. and P. J. Higgins. 1990. Handbook of Australian, New Zealand and Antarctic birds, vol. 1: ratites to ducks. Part A: ratites to petrels. Oxford University Press, Melbourne, Australia.

Murie, J. O., L. S. Davis and I. G. McLean. 1991. Identifying the sex of Fiordland Crested Penguins by morphometric characters. Notornis 38: 233-238.

Palma, L., S. Mira, P. Cardia, P. Beja, T. Guillemaud, N. Ferrand, M. L. Cancela and L. C. Da Fonseca. 2001. Sexing Bonelli's Eagle nestlings: morphometrics versus molecular techniques. Journal of Raptor Research 35: 187-193.

Poisbleau, M., L. Demongin, H. J. van Noordwijk, I. J. Strange and P. Quillfeldt. 2010. Sexual dimorphism and use of morphological measurements to sex adults, immatures and chicks of Rockhopper Penguins. Ardea 98: 217-224.

Sagar, P. M., J. C. Stahl and J. Mollof. 1998. Sex determination and natal philopatry of Southern Buller's Mollymawks (Diomedea bulleri bulleri). Notornis 45: 271-278.

Scolaro, J. A. 1987. Sexing fledglings and yearlings of Magellanic Penguins by discriminant analysis of morphometric measurements. Colonial Waterbirds 10: 50-54.

Setiawan, A. N., J. T. Darby and D. M. Lambert. 2004. The use of morphometric measurements to sex Yellow-eyed Penguins. Waterbirds 27: 96-101.

StatSoft, Inc. 2007. STATISTICA v. 8.0. StatSoft, Inc., Tulsa, Oklahoma. http://www.statsoft.com, accessed 12 July 2015.

Titus, K., J. A. Mosher and B. K. Williams. 1984. Chancecorrect classification for use in discriminant analysis: ecological applications. American Midland Naturalist 111: 1-7.

Warham, J. 1972. Breeding seasons and sexual dimorphism in Rockhopper Penguins. Auk 89: 86-105.

Warham, J. 1975. The crested penguins. Pages 189-269 in The Biology of Penguins (B. Stonehouse, Ed.). Macmillan Press, London, U.K.

William, B. K. 1983. Some observations on the use of discriminant analysis in ecology. Ecology 64: 1283-1291. 